\title{
Identification, susceptibility, and detection of integron-gene cassettes of Arcanobacterium pyogenes in bovine endometritis
}

\author{
M.-C. Liu, ${ }^{*} \dagger$ C.-M. Wu, ${ }^{*}$ Y.-C. Liu, $†$ J.-C. Zhao, $†$ Y.-L. Yang, $†$ and J.-Z. Shen ${ }^{* 1}$ \\ *Department of Pharmacology and Toxicology, College of Veterinary Medicine, China Agricultural University, Beijing 100193, P. R. China \\ †College of Animal Husbandry and Veterinary Medicine, Shenyang Agricultural University, Shenyang 110161, P. R. China
}

\begin{abstract}
The present study aimed to identify, determine the susceptibility, and detect gene cassettes of Arcanobacterium (Actinomyces) pyogenes isolates from cows with endometritis. Arcanobacterium pyogenes isolates were identified first by using the API Coryne Vit system test, and further through PCR. Minimum inhibitory concentrations of 23 antimicrobial agents against $A$. pyogenes were tested using standard broth microdilution assays according to the protocols of the Clinical and Laboratory Standards Institute. The genes of integrons I and II were amplified by PCR using specific primers. Thirty-two A. pyogenes isolates were isolated from 136 endometritic cows in the Hohhot region. Antibiotic susceptibility tests revealed that all isolates were highly sensitive to fluoroquinolones $(100 \%)$, macrolides ( $~ 81.2$ to $100 \%)$ and florfenicol $(90.6 \%)$, aminoglycosides $(\sim 15.6$ to $81.2 \%)$, and tetracyclines $(\sim 43.7$ to $68.7 \%)$. However, $53.1 \%$ were resistant to clindamycin, $\sim 50$ to $65.6 \%$ were resistant to penicillins, and $\sim 37.5$ to $71.9 \%$ were resistant to cephalosporins. One hundred percent were resistant to sulfonamides and bacitracin zinc. The integrons were further confirmed by sequencing. No class II integrons were detected, whereas $50 \%(\mathrm{n}=16)$ of the A. pyogenes isolates were positive for the presence of the intI I gene, but only 13 contained gene cassettes. Sequence analysis of gene cassettes revealed 6 gene cassettes, 4 of which encode resistant determinants of aminoglycosides (aadA1, aadA5, aadA24, and aadB) and 1 of which encodes the resistance gene of chloramphenicol (cmlA6). The function of the sixth identified cassette, designated ORF1, is unknown. The gene cassette arrays aadA24-ORF1, aadA5, and aadA1-addBcmlA6 were found in $46.13 \%$ (6/13), $38.46 \%$ (5/13), and $38.46 \%(5 / 13)$ of the isolates, respectively. These cassettes segregated according to a consistent pattern, with aadA5 always alone, ORF1 always with aadA24,
\end{abstract}

Received September 28, 2008.

Accepted April 21, 2009.

${ }^{1}$ Corresponding author:sjz@cau.edu.cn and aadA1-aadB and cmlA6 always together. Most of the positive integrons existed in the multiresistant isolates ( $\mathrm{n}=\sim 3$ to 7 ), indicating that the integrons played an important role in the dissemination and spread of antimicrobial resistance. This is the first report of $A$. pyogenes infections in dairy cows in China and of detection of gene cassettes and integrons in A. pyogenes.

Key words: Arcanobacterium (Actinomyces) pyogenes, antimicrobial susceptibility, integron, gene cassette

\section{INTRODUCTION}

Arcanobacterium (Actinomyces) pyogenes is one of the important opportunistic pathogens of the upper respiratory and genital tracts of cattle, sheep, swine, and many other species (Billington et al., 2002a; Azawi and Azar, 2003; Gröhn et al., 2004; Ertaş et al., 2005). The prevalence of $A$. pyogenes from dairy cows was 32.9 and $17.6 \%(\mathrm{n}=85)$ at $\mathrm{d} 26$ and 40 postpartum, respectively (Bonnett et al., 1991). The isolation of A. pyogenes was positively correlated with the isolation of anaerobic bacteria at d 26, which resulted in increased uterine lesions at d 40 (Bonnett et al., 1991), and A. pyogenes was found in $70 \%$ of the uteri of postparturient dairy cows (Cohen et al., 1996). Novel reports showed that the uterine infection could be classified as puerperal metritis, clinical metritis, clinical endometritis, or subclinical endometritis (Földi et al., 2006; Sheldon et al., 2006); that the prevalence of $A$. pyogenes was higher within 26 d postpartum than at $40 \mathrm{~d}$ postpartum; and that the coinfection of $A$. pyogenes and anaerobic bacteria could increase uterine lesions, decreasing the chance of successful treatment in dairy cows. Rutter et al. (1999) reported that at 4 to $7 \mathrm{~d}$ postpartum, $40 \%(26 / 65)$ of cows with puerperal metritis were positive for $A$. pyogenes and $\beta$-hemolytic Streptococcus. Arcanobacterium pyogenes and $\beta$-hemolytic Streptococcus were isolated for periods of at least 24 to $27 \mathrm{~d}$ postpartum (Rutter et al., 1999). The uterine coinfection with A. pyogenes and other anaerobic or $\beta$-hemolytic Streptococcus has been shown to result in increased purulent secretion, early embryonic death, and infertility (Nolte et al., 2001; Gilbert et al., 2005). 
Because of the lack of an effective vaccine for uterine infections caused by $A$. pyogenes, a longstanding treatment for this condition is either $\mathrm{PGF}_{2 \alpha}$ analogs or antibiotics (Steffan et al., 1984). However, the extensive use of antibacterials has resulted in the increasing resistance of pathogenic bacteria (Trinh et al., 2002; Sheldon et al., 2004). The creation of bacterial drug resistance can eventually jeopardize the successful treatment of disease in both humans and animals. For instance, the effect of antibiotic treatment on cow endometritis has been attenuated by emerging resistant strains (Cohen et al., 1996; Ali 2000; Trinh et al., 2002). As Sheldon et al. (2004) reported, many A. pyogenes isolated from cattle with clinical metritis, endometritis, or both were resistant to oxytetracycline, which had the highest MIC value $\left(16 \mathrm{mg} \cdot \mathrm{L}^{-1}\right)$, but all were susceptible to 3 cephalosporins (cefquinome, cephapirin, and ceftiofur, MIC $<0.6 \mathrm{mg} \cdot \mathrm{L}^{-1}$ ). Cohen et al. (1996) reported that all A. pyogenes isolates from uteri of postparturient dairy cows were susceptible to clindamycin, and most isolates were susceptible to ciprofloxacin. On the other hand, antimicrobial susceptibility of $A$. pyogenes strains isolated from cattle showed that up to 25.9 and $22.2 \%$ were resistant to tetracyclines and macrolides, respectively (Trinh et al., 2002). Penicillin was highly effective against $A$. pyogenes (Guerin-Faublee et al., 1993; Ali, 2000).

In resistance mechanism research, Billington et al. (2002b) elucidated that the antimicrobial resistance gene Tet $W$ mediated the $A$. pyogenes resistance to tetracycline. ErmX and $\operatorname{ErmB}$ were found in tylosinresistant $A$. pyogenes isolates from animals (Jost et al., 2003, 2004). Integrons are DNA elements that include the gene's determinant group and insertion site for a site-specific recombination system, which enables them to capture mobile gene cassettes (Collis and Hall, 1992). The expression of an integron may induce bacterial multidrug resistance and cause the resistance gene to disseminate in the same and different germs by a conjugative plasmid (Rowe-Magnus et al., 2002). However, gene cassette-integron detection from $A$. pyogenes has not been reported in bovine endometritis.

In this study, 136 cows with endometritis from 15 dairy farms from Hohhot, Inner Mongolia Autonomous Region of China, were sampled for A. pyogenes. In addition, MIC of 23 commonly used antibiotics were determined by standard broth microdilution. Eventually, the gene cassettes-integrons were detected by PCR, and the correlation between integrons and resistance was analyzed. The goals of this investigation were 3-fold: 1) to provide data on the prevalence of antimicrobial resistance in strains of $A$. pyogenes isolated from cattle in the Inner Mongolia Autonomous Region of China; 2) to elucidate the resistance mechanisms of these strains; and 3) to facilitate the correct antibiotic treatment in cases of endometritis in the region.

\section{MATERIALS AND METHODS}

\section{Bacteria Isolation and Characterization of the A. pyogenes Reference Strain}

The reference A. pyogenes strain ATCC 19411 (NCTC 5224, purchased from American Type Culture Collection, Manassas, VA) was cultured on brain heart infusion agar (Difco, Franklin Lakes, NJ) containing $5 \%$ defibrinated sheep blood, and incubated for $48 \mathrm{~h}$ at $37^{\circ} \mathrm{C}$. Glycerol stocks $(20 \%)$ were made and stored at $-80^{\circ} \mathrm{C}$ until use.

\section{Sample Collection}

From June to December in 2006, we investigated the prevalence of metritis and endometritis on 15 dairy farms in Hohhot, Inner Mongolia. A total of 136 Holstein cows showing signs of postpartum metritis or endometritis, as diagnosed by veterinarians or herd owners (552 cows postpartum were involved), were sampled, including 4 cases of puerperal metritis (with an abnormally enlarged uterus and a watery red-brown uterine secretion, fever exceeding $39.5^{\circ} \mathrm{C}$, decreased milk yield within $15 \mathrm{~d}$ postpartum, with no treatment before sampling), 8 cases of clinical metritis (with a large uterus and a purulent uterine discharge within 21 d postpartum), 52 cases of clinical endometritis (with a heavy purulent or mucopurulent discharge after $21 \mathrm{~d}$ postpartum), and 72 cases of subclinical endometritis (after 30 to $50 \mathrm{~d}$ postpartum).

Some postpartum cows diagnosed with metritis or endometritis by veterinarians or herd owners were treated with antibacterials; however, antibacterials were given to endometritic cows by veterinarians or herd owners only once. There was no abatement of the clinical symptoms of cows with endometritis, and the sample was collected promptly at this time. Penicillin or ampicillin and aminoglycosides were used to treat 18 cows with metritis or endometritis (5 cases of clinical endometritis and 13 cases of subclinical endometritis), oxytetracycline was used to treat 15 cases ( 7 cases of clinical endometritis and 8 cases of subclinical endometritis), and ceftiofur was used in 31 cases (11 cases of clinical endometritis and 20 cases of subclinical endometritis). The other samples were collected from cows not treated with antibiotics.

Uterine secretions were collected using a chlamydsemen deposition gun through a sterile procedure. The sample was removed to a sterile vial with buffered glycerol saline, and the vials were placed in a cooler with 
ice and immediately delivered to the laboratory within $2 \mathrm{~h}$.

\section{Biochemical Characterization}

A $50-\mu \mathrm{L}$ uterine secretion sample from each cow was inoculated onto blood agar plates supplemented with $5 \%$ defibrinated sheep blood and $100 \mathrm{U} / \mathrm{mL}$ of polymyxin $\mathrm{B}$ and incubated with $5 \% \mathrm{CO}_{2}$ at $37^{\circ} \mathrm{C}$ for $48 \mathrm{~h}$ to isolate A. pyogenes. Smooth, glistening colonies surrounded by a conspicuous $\beta$-hemolytic zone were presumed to be A. pyogenes. Initial identification of these presumptive $A$. pyogenes was based on conventional methods, including gram stain, colony morphology, and bacterial morphology. These isolates were further identified using the API Coryne Vit system (bioMérieux SA, Marcy l'Etoile, France). The confirmed A. pyogenes isolates were stored at $-80^{\circ} \mathrm{C}$ in brain heart infusion agar plus $20 \%$ glycerol until resuscitation.

Fifty-microliter aliquots of uterine secretions were inoculated onto different agar plates, such as MacConkey agar, manitol salt agar, cetrimide agar, mannitol-egg yolk-polymyxin B agar, and selective Streptococcus agar modified number 2 (Acumedia, Lansing, MI). These plates were subsequently incubated at $37^{\circ} \mathrm{C}$ for $24 \mathrm{~h}$, and anaerobic CDC (Centers for Disease Control and Prevention) blood agar plates (Sigma, St. Louis, MO) cultured in anaerobic chambers (Bactron III-2E, Shellab, Cornelius, OR) at $37^{\circ} \mathrm{C}$ for $48 \mathrm{~h}$ to isolate anaerobic bacteria. Putative pathogenic bacteria, as judged by colony morphology and gram staining, were further identified by API kits (bioMérieux SA): API 20 E, API Staph, API 20 NE, API 50 CHB, API Strep, and API 20 A for Escherichia coli, Staphylococcus aureus, Bacillus aeruginosus, Bacillus cereus, Streptococcus, and anaerobic bacteria, respectively. Strains ATCC 25922, ATCC 29213, ATCC 27853, ATCC 11778, ATCC 19615, and ATCC 13124 were used as positive controls, respectively.

\section{Sequencing of the 16 S rRNA Gene}

To further identify and classify the isolated strains and analyze their evolution status, the 16S rRNA gene of A. pyogenes isolates was sequenced. Genomic DNA of A. pyogenes isolates was extracted using the MiniBEST Bacterial Genomic DNA Extraction Kit, version 2.0 (TaKaRa, Dalian, China). The 16S rRNA gene of $A$. pyogenes was amplified by PCR using universal primers (forward: 5'-CCGAATTCGTCGACAACAGAGTTTGATCCTGGCTCAG-3'; reverse: 5'-CCCGGGATCCAAGCTTACGGCTACCTTGTTACGACTT-3') as described previously (Weisburg et al., 1991; Ramos, et al., 1997; Narayanan et al., 1998; Jost et al., 2002). Poly- merase chain reaction products were purified and cloned for sequencing. Nucleotide sequencing was performed with an ABI Prism Big Dye Primer Cycle Sequencing Ready Reaction Kit and ABI 377 DNA autosequencing machine using T7 and SP6 primers (TaKaRa), and analyzed with DNASTAR software (DNASTAR Inc., Madison, WI) and the program NCBI-BLAST (http:// www.ncbi.nlm.nih.gov).

\section{Antibacterial Susceptibility Assay}

The following antimicrobial agents were provided by The Chinese Institute of Veterinary Drug Control (Beijing, China): ciprofloxacin, ofloxacin, enrofloxacin, gatifloxacin, streptomycin, gentamicin, amikacin, oxytetracycline, tetracycline, doxycycline, penicillin G, amoxicillin, oxacillin, cefazolin, ceftiofur, sulfadiazine, sulfamethoxydiazine, florfenicol, erythromycin, tilmicosin, azithromycin, clindamycin, and bacitracin zinc. The 23 antimicrobial agents in this study included 10 classes of antibiotics, with 4 in the fluoroquinolones, 3 in the aminoglycosides, 3 in the tetracyclines, 3 in the penicillins, 2 in the cephalosporins, 2 in the sulfonamides, 3 in the macrolides, and 1 each in the chloramphenicols, lincosamides, and polypeptide antibiotics, respectively.

Antibacterial MIC against A. pyogenes were assayed using a standard broth dilution method, with final inocula of $4 \times 10^{5} \mathrm{cfu} / \mathrm{mL}$ on Müller-Hinton medium supplemented with $5 \%$ fetal calf serum as outlined by the Clinical and Laboratory Standards Institute (2007). The reference strain ATCC 19411 was used as a control on each plate, as described previously (Guerin-Faublee et al., 1993; Lehtolainen et al., 2003; Pitkälä et al., 2004). Minimum inhibitory concentration values were analyzed by $\mathrm{MIC}_{50}$ and $\mathrm{MIC}_{90}\left(\mathrm{MIC}_{50}=\mathrm{MIC}, 50 \%\right.$ growth inhibition; $\mathrm{MIC}_{90}=\mathrm{MIC}, 90 \%$ growth inhibition).

\section{Detection of the Integrase Gene and Gene Cassettes}

The template DNA for PCR was prepared by the MiniBEST Bacterial Genomic DNA Extraction Kit, version 2.0 (TaKaRa). The general strategies for PCR detection of various types of integrons and gene cassettes were according to the methods described by Hall and Collis (1995) and Bass et al. (1999). Specific primers used for PCR detection of the integrase gene (intI I and intI II) and gene cassette region are shown in Table 1. All positive amplicons were purified and cloned for sequencing. The sequencing and data analysis of the integrase gene and gene cassettes were similar to that of the $16 \mathrm{~S}$ rRNA gene. 


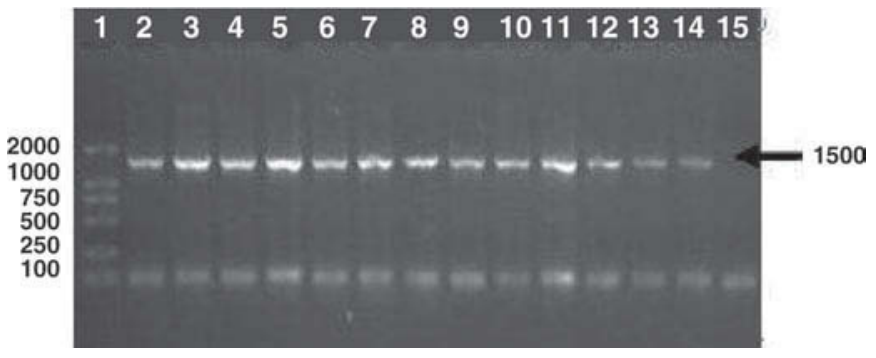

Figure 1. Agarose gel electrophoresis of PCR products of the $16 \mathrm{~S}$ rRNA gene obtained from Arcanobacterium pyogenes. 1: DL2000 DNA marker (TaKaRa, Dalian, China); 2: ATCC 19411 positive control; 3 to 14: isolation strains; 15 : negative control.

\section{RESULTS}

\section{Isolation and Characterization of Bacteria from Bovine Endometritis}

Thirty-two A. pyogenes colonies presumed by gram stain, colony morphology, and bacterial morphology compared with ATCC 19411 were further identified by the API Coryne Vit system (bioMérieux SA); the positive rate of $A$. pyogenes was $23.5 \%(32 / 136)$. In addition, other pathogenic bacteria from dairy cow endometritis were identified through API: 57 E. coli, 7 Staph. aureus, 15 B. cereus, 47 Streptococcus [Aerococcus viridans (15/47), Streptococcus bovisII (7/47), Enterococcus faecium (11/47)], and 14 anaerobic bacteria (3 Clostridium naeslundii, 3 Clostridium bifermentans, 4 Clostridium perfringens, 2 Clostridium beijerinckii, and 2 Prevotella intermedia). Bacillus aeruginosus was not obtained. Fifteen cases were coinfections of $A$. pyogenes with $E$. coli, and 4 cases were coinfection of $A$. pyogenes, E. coli, and anaerobic bacteria.

The 16S rRNA genes of 32 isolates were amplified, cloned, and sequenced using universal PCR primers. Approximate 1.5-kb fragments were obtained from the PCR assays (Figure 1). Sequence alignment analysis by using the GenBank database revealed that the $16 \mathrm{~S}$ rRNA sequences of all these isolates were highly homologous to the ATCC 19411 (X79225, NCTC 5224; homology rate $\sim 99$ to $100 \%$ ). Seventeen strains' sequence were identical to ATCC 19411 (homology rate 100\%).
Therefore, all 32 isolates were identified as A. pyogenes. The 16S rRNA gene sequences of some isolates in this study have been submitted to the GenBank database, with accession numbers EU268194 (RY10-1), EU268193 (HC-H10), EU268191 (HC-H13-2), EU268192 (RY042), EU267794 (BM-H07-1), EU267795 (RY11-3), and EU308588 (TZQ 01), respectively.

\section{Antimicrobial Susceptibility}

As shown in Table 2, all A. pyogenes isolates were highly susceptible to fluoroquinolones, such as ciprofloxacin, gatifloxacin, enrofloxacin, and ofloxacin, with $\mathrm{MIC}_{90}$ at 2.0, 2.0, 1.0, and $0.5 \mu \mathrm{g} / \mathrm{mL}$ for ciprofloxacin, gatifloxacin, enrofloxacin, and ofloxacin, respectively. Similarly, all isolates were susceptible to tilmicosin and azithromycin, and $82.2 \%$ isolates were susceptible to erythromycin, with MIC in the range of 0.0625 to $\geq 32$ $\mu \mathrm{g} / \mathrm{mL}$. Some A. pyogenes isolates were resistant to florfenicol (9.4\%), gentamicin (18.8\%), cefazolin (37.5\%), and amikacin (40.6\%). However, high resistance rates were observed in penicillins, including penicillin $\mathrm{G}$ (65.6\%), amoxicillin (50\%), and oxacillin (56.3\%), with $\mathrm{MIC}_{90}$ of 4 to $8 \mu \mathrm{g} / \mathrm{mL}$, and cephalosporins, such as ceftiofur (71.9\%) and cefazolin (37.5\%). The same tendency was discovered in oxytetracycline $(53.1 \%)$, tetracycline (68.8\%), and doxycycline (62.5\%), with relatively high $\mathrm{MIC}_{90}$ of 16 to $32 \mu \mathrm{g} / \mathrm{mL}$. Moreover, all isolates were resistant to sulfadiazine, sulfamethoxydiazine, and bacitracin zinc.

\section{Detection and Characterization of the Integrase Gene and Gene Cassettes}

As shown in Table 3, class II integrons was not detected, whereas $50 \%(\mathrm{n}=16 / 32)$ of the isolates were positive for the intI I, which was the marker for class I integrons (Figure 2). Consequently, the gene cassettes were cloned and sequenced. The integrons were found to harbor 1 or 2 gene cassettes, and combinations of these gene cassettes are shown in Table 3 . These gene cassettes existed in multiresistant $(\mathrm{n}=\sim 3$ to 7$)$ isolates and included genes encoding aminoglycoside resistance

Table 1. Polymerase chain reaction primers and the results of detection

\begin{tabular}{|c|c|c|c|c|}
\hline Gene & PCR primer & $\begin{array}{l}\text { Expected size of PCR } \\
\text { product (bp) }\end{array}$ & Reference & $\begin{array}{l}\text { No. positive } \\
\quad(\mathrm{n}=32)\end{array}$ \\
\hline $\operatorname{intI} \mathrm{I}$ & $\begin{array}{l}\text { Forward: CCTCCCGCACGATGATC } \\
\text { Reverse: TCCACGCATCGTCAGGC }\end{array}$ & 280 & Bass et al. (1999) & $16 / 32$ \\
\hline intI II & $\begin{array}{l}\text { Forward: TTATTGCTGGGATTAGGC } \\
\text { Reverse: ACGGCTACCCTCTGTTATC }\end{array}$ & 233 & Hall and Collis (1995) & $0 / 32$ \\
\hline Cassette & $\begin{array}{l}\text { Forward: GGCATCCAAGCAGCAAG } \\
\text { Reverse: AAGCAGACTTGACCTGA }\end{array}$ & Unpredictable & Bass et al. (1999) & $13 / 32$ \\
\hline
\end{tabular}


Table 2. In vitro susceptibilities of 32 Arcanobacterium pyogenes strains isolated from cow endometritis

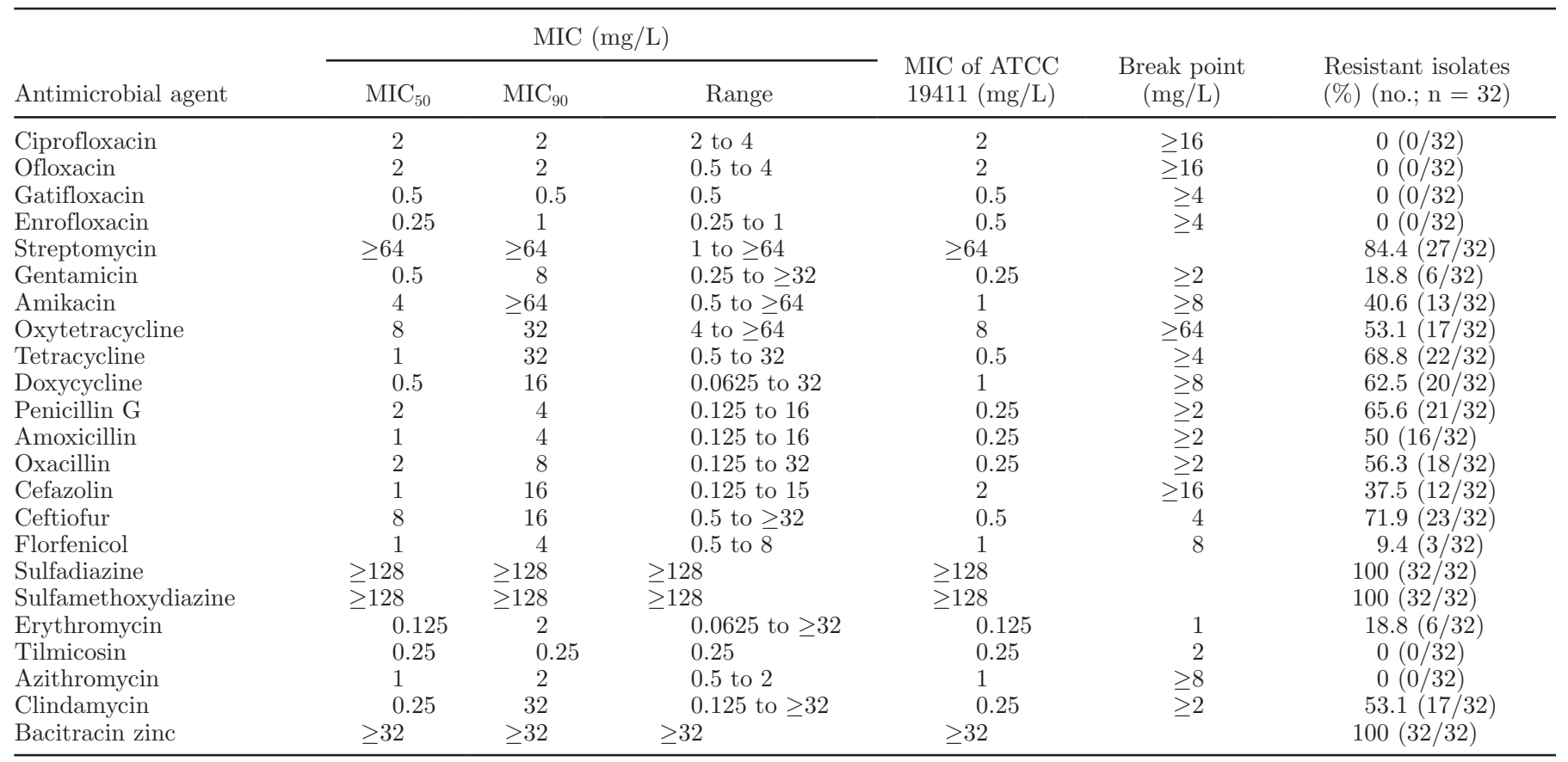

(aadA1, aadA5, aadA24, and aadB), chloramphenicol resistance ( $\mathrm{cmlA} 6$ ), and ORF1, respectively. The 1,048and 1,608-bp amplicons were revealed to contain aadA5 and aadA24-ORF1 gene cassettes, respectively, and the 3,149-bp amplicon included aadA1-aadB-cmlA6 gene cassettes (Figure 3).

\section{DISCUSSION}

The presence of pathogenic bacteria, including $E$. coli and $A$. pyogenes, disrupts ovarian follicle growth and function (LeBlanc, 2008; Sheldon et al., 2008). Arcanobacterium pyogenes was the predominant aerobic species; it was found previously in $40 \%$ of the samples (Rutter et al., 1999). The isolation rate of $A$. pyogenes from dairy cows was higher at d 26 and 40 postpartum (32.9 and $17.6 \%$, respectively), and the coinfection of $A$. pyogenes and anaerobic bacteria could increase uterine lesions (Bonnett et al., 1991).

In this paper, the cows sampled were classified as having puerperal metritis, clinical metritis, clinical endometritis, or subclinical endometritis, according to the reports of Sheldon et al. (2008) and Földi et al. (2006). This study showed that the positive rate of $A$. pyogenes from the uteri of bovines with metritis or endometritis was $23.5 \%$; $65.6 \%(21 / 32)$ A. pyogenes were isolated from cows with metritis and clinical endometritis. Meanwhile, $12.5 \%(4 / 32)$ of the cases infected with A. pyogenes were coinfections of A. pyogenes, E. coli, and anaerobic bacteria, 2 cases of which were within
15 d postpartum and 2 cases of which were within 21 d postpartum. The finding that $46.9 \%(15 / 32)$ of the cases were coinfections of $A$. pyogenes and $E$. coli was consistent with the report of Cohen et al. (1996), who found aerobic and anaerobic bacterial coinfections in $55 \%$ of the samples. There was a strong association between isolation of A. pyogenes and Streptococcus within $21 \mathrm{~d}$ postpartum. Further study of the effect of coinfection on uterine lesions and cow reproductive capacity should be carried out. Because antibacterials were given to endometritic cows by veterinarians or herd owners only once, there was hardly any abatement of the clinical symptoms of cows with endometritis. Samples were collected promptly at this time, when the resistance might not be developed. Of the $32 \mathrm{~A}$. pyogenes isolates, only 6 were from cows treated with antibacterials before sampling. For example, although 4 of the $6 \mathrm{~A}$. pyogenes isolates were resistant to penicillin $\mathrm{G}$, the resistance level was not obviously different from that of untreated cows.

The antimicrobials examined in this study are available for food-producing animals in China, and their withdrawal times have been defined. The actions of some antibacterial agents were not affected by purulent materials, such as $\beta$-lactam antibacterial and aminoglycoside agents, but the action of sulfonamides was largely affected by the intrauterine discharge. In additional, antimicrobial agents are administrated intrauterine after the uterus has been washed with sodium chloride, during which large amounts of intrauterine liquid were 


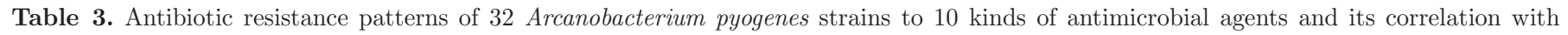
occurrence of the integrons

\begin{tabular}{|c|c|c|c|c|}
\hline Resistance patterns $^{1}$ & $\begin{array}{l}\text { No. of resistant } \\
\text { strains }(\mathrm{n}=32)\end{array}$ & $\begin{array}{c}\text { Rate of resistance } \\
\text { patterns } \\
(\%)\end{array}$ & $\begin{array}{c}\text { Detection rate } \\
\text { of class I integrons }{ }^{2} \\
(\%)(\text { no. } ; \mathrm{n}=32)\end{array}$ & $\begin{array}{l}\text { Inserted gene cassettes (order } \\
\text { in the resistant strains) }\end{array}$ \\
\hline $\mathrm{sb}$ & 1 & 3.1 & -3 & - \\
\hline $\mathrm{sbc}$ & 5 & 15.6 & $6.3(2)$ & aadA1-addB-cmlA6 (1) \\
\hline sbp & 3 & 9.4 & $3.1(1)$ & $\operatorname{aadA} 5$ (1) \\
\hline $\operatorname{sbpc}$ & 2 & 6.3 & - & - \\
\hline sbcl & 2 & 6.3 & - & - \\
\hline sbcg & 1 & 3.1 & $3.1(1)$ & aadA24-ORF1 (1) \\
\hline sbce & 1 & 3.1 & - & - \\
\hline sbpl & 1 & 3.1 & - & - \\
\hline sbcep & 1 & 3.1 & $3.1(1)$ & aadA1-addB-cmlA6 (1) \\
\hline sbple & 1 & 3.1 & $3.1(1)$ & aadA24-ORF1 (1) \\
\hline sbcfl & 2 & 6.3 & $6.3(2)$ & $\operatorname{aadA} 5(1)$ \\
\hline sbcpo & 1 & 3.1 & $3.1(1)$ & aadA5, aadA1-addB-cmlA6 (1) \\
\hline sbcpl & 3 & 9.4 & $3.1(1)$ & aadA24-ORF1 (1) \\
\hline sbcgp & 1 & 3.1 & - & - \\
\hline sbcgpl & 2 & 6.3 & $3.1(1)$ & aadA24-ORF1 (1) \\
\hline sbfgpl & 2 & 6.3 & $6.3(2)$ & aadA1-addB-cmlA6 (2) \\
\hline sbcepl & 1 & 3.1 & $3.1(1)$ & aadA24-ORF1 (1) \\
\hline sbceopl & 2 & 6.3 & $6.3(2)$ & aadA5, aadA24-ORF1 (1) \\
\hline
\end{tabular}

${ }^{1}$ Abbreviations for antimicrobial agents: $\mathrm{s}=$ sulfadiazine; $\mathrm{b}=$ bacitracin zinc; $\mathrm{p}=$ penicillin $\mathrm{G}$; $\mathrm{c}=$ ceftiofur; $\mathrm{e}=$ erythromycin; $\mathrm{f}=\mathrm{florfenicol}$; $\mathrm{g}=$ gentamicin $; \mathrm{l}=$ clindamycin; $\mathrm{o}=$ oxytetracycline.

${ }^{2}$ Class I integrons were detected in $16 \mathrm{~A}$. pyogenes isolates, but only 13 contained gene cassettes. Class II integrons were not detected in any $A$. pyogenes isolate.

${ }^{3} \mathrm{~A}$ dash indicates not detected.

discarded; thus, the factors that affected the drug action had been reduced as much as possible.

As shown in Table 2, most of the A. pyogenes isolates were susceptible to gentamicin but were highly resistant to streptomycin, clindamycin, and tetracyclines. Similar findings were reported by Guerin-Faublee et al. (1993), who found that despite A. pyogenes being isolated from diverse animals and samples, only 4 were recovered from uterine discharges. However, Cohen et al. (1996) reported that all isolates from the uteri of dairy cows were susceptible to clindamycin and that most isolates were resistant to tetracycline. Trinh et al. (2002) showed that A. pyogenes isolated from bovines had different resistance rates to tetracyclines (25.9\%) and macrolides (22.2\%), respectively. In addition, penicillin has been shown to be highly effective against $A$. pyogenes (Guerin-Faublee et al., 1993; Ali, 2000). In this study, $65.6 \%$ of the isolates were resistant to penicillin and $56.3 \%(18 / 32)$ were resistant to oxytetracycline; this is higher than in the previous reports of Trinh et al. (2002) and Sheldon et al. (2004; MIC $_{50}$ of 16 $\mu \mathrm{g} / \mathrm{mL}$ ). The difference may be due to penicillins and oxytetracycline being used to treat bovine endometritis in China. No isolate was resistant to quinolones, which may have been caused by overuse of penicillin for endometritis therapy, with quinolones being used less in veterinary medicine.

In the multiresistant isolates, the resistance rates to penicillin $\mathrm{G}$, amoxicillin, and oxacillin were very similar to each other, suggesting high cross-resistance rates in penicillins. However, $50.0 \%$ of these isolates were resistant to more than 5 antibiotics, with very high MIC values. The different resistance patterns were probably due to the different aims and kinds of antimicrobial agents used on these dairy farms.

According to prior reports, the rate of gene cassettesintegrons in gram-negative bacteria was higher than that in gram-positive bacteria, and these integrons also played significant roles in transfer of the antimicrobial resistance gene. Keyes et al. (2000) reported that the positive-integron incidence rate in $E$. coli isolates from chickens was $82 \%$. Wang et al. (2008) reported that it

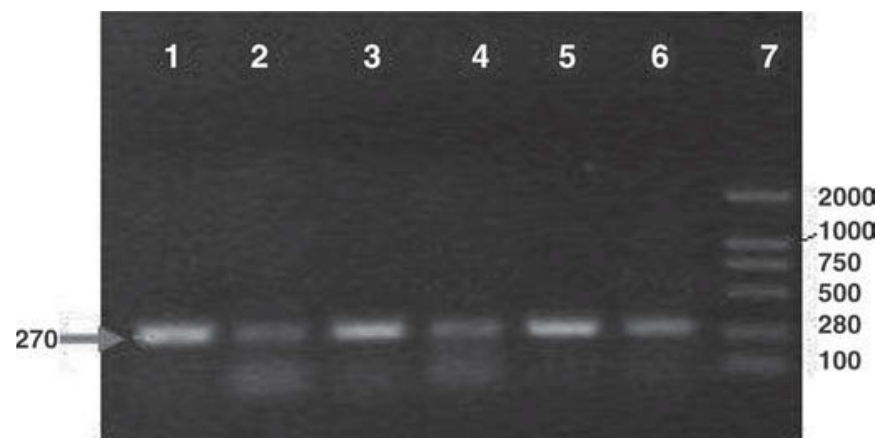

Figure 2. Agarose gel electrophoresis of the intI I gene amplification fragment. 1 to 6: intI I gene positive isolates; 7: DL2000 DNA marker (TaKaRa, Dalian, China). 


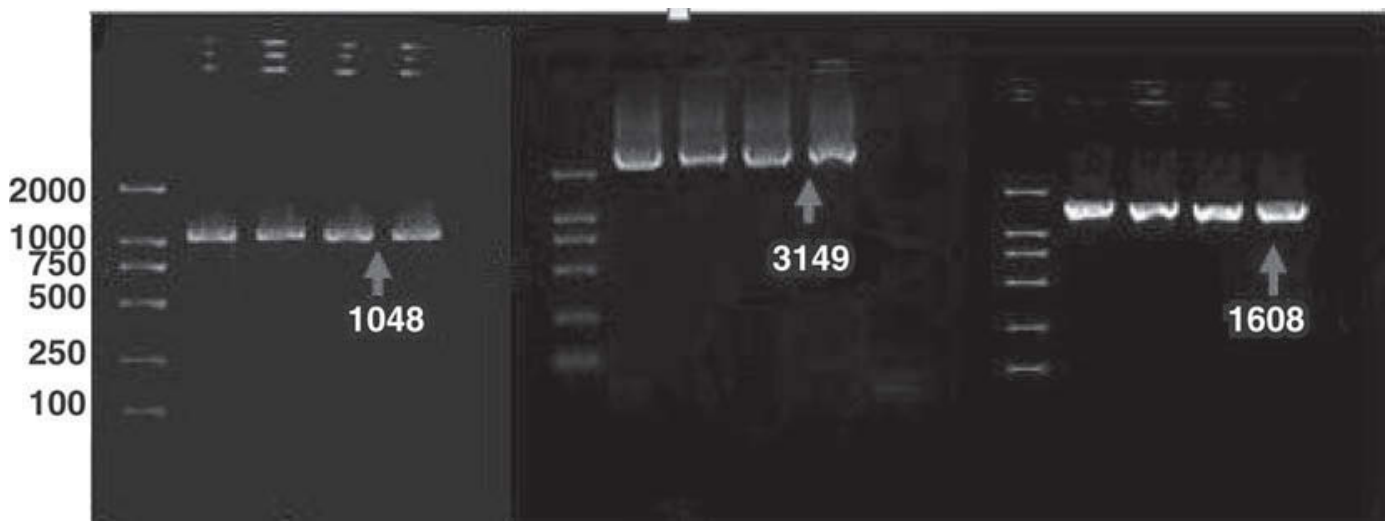

Figure 3. Agarose gel electrophoresis of gene cassette amplification products. Left) 1,048 bp; Center) 3,149 bp; Right) 1,608 bp.

was $56.90 \%$ from bovine mastitis. Antunes et al. (2006) found that there were 1 or 2 class I integrons among Salmonella. However, no gene cassettes-integrons were reported among $A$. pyogenes. In the present study, the positive integron rate was $50 \%(16 / 32)$ from $A$. pyogenes isolates, but the rate of gene cassettes among these integrons was $81.25 \%(13 / 16)$, and integrons in the other 3 isolates were empty. This is the first report of the gene cassettes-integrons in $A$. pyogenes. It has been indicated that the detection rate of integrons is related to the antimicrobial resistance of $A$. pyogenes (Rowe-Magnus et al., 2002).

The discovery of antimicrobial resistance gene cassettes in this study revealed that aminoglycosideresistance determinants (aadA5, aadA24, and aadB), chloramphenicol-resistance determinants ( $c m l A 6)$, and ORF1 (whose function is not known) were prevalent among A. pyogenes strains isolated from cow endometritis, and these resistance genes were carried by I integrons in genomic DNA. The gene cassette arrays were different from those of other resistant bacteria. Although aadA5, aadB, and cmlA6 had been detected in E. coli and Salmonella, the cassette arrangements were different in these bacteria: gene cassettes of $d f r A 17$ $a a d A 5$ and $a a d B$ - $a a d A 1$ or $a a d B$-cmlA1 were frequently discovered in E. coli (Kang et al., 2005; Chang et al., 2007; Wang et al., 2008), whereas dfrA1-aadA24 was found in Salmonella (Rodríguez et al., 2008). In this study, the addB-cmlA 6 array was a novel type of cassette arrangement. These cassettes segregated according to a consistent pattern, with aadA5 always alone, ORF1 always with aadA24, and aadA1-aadB and $c m l A 6$ always together. This may be explained by antibiotic selective pressure and resistance transfer between different bacterial species.

However, the class I integron examined in this study did not account for the total resistance phenotype observed among the A. pyogenes isolates from cow endometritis, such as that there was high resistance of $A$. pyogenes isolates to $\beta$-lactams, macrolides, and tetracyclines, which could possibly be attributed to the presence of other mobile DNA elements or some undetectable resistance genes. Further investigations are needed to assess determinants of antimicrobial resistance other than integron-mediated resistance in these isolates.

\section{ACKNOWLEDGMENTS}

This study was supported by the National Key Technologies R\&D Program on Food Safety for the 11th FiveYear Plan from the Ministry of Science and Technology of P. R. China (Beijing, China; no. 2006BAK02A03). The authors are grateful to the faculty members in the Department of Pharmacology and Toxicology, College of Veterinary Medicine, China Agricultural University, for their cooperation.

\section{REFERENCES}

Ali, H. S. 2000. Clinical, bacteriological and therapeutic studies on mixed infection with Actinomyces bovis and Actinomyces pyogenes in buffaloes in Assiut Governorate, Egypt. J. Assiut Vet. Med. 44:112-121.

Antunes, P., J. Machado, and L. Peixe. 2006. Characterization of antimicrobial resistance and class 1 and 2 integrons in Salmonella enterica isolates from different sources in Portugal. J. Antimicrob. Chemother. 58:297-304.

Azawi, O. I., and Z. A. J. Azar. 2003. Bacteriological and histopathological studies in repeat breeder cows. Iraqi J. Vet. Sci. 16:49-59.

Bass, L., C. A. Liebert, M. D. Lee, A. O. Summers, D. G. White, S. G. Thayer, and J. J. Maurer. 1999. Incidence and characterization of integrons, genetic elements mediating multiple-drug resistance, in avian Escherichia coli. Antimicrob. Agents Chemother. 43:29252929.

Billington, S. J., K. W. Post, and B. H. Jost. 2002a. Isolation of Arcanobacterium (Actinomyces) pyogenes from cases of feline otitis externa and canine cystitis. J. Vet. Diagn. Invest. 14:159-162.

Billington,, S. J., J. G. Songer, and B. H. Jost. 2002b. Widespread distribution of a Tet $W$ determinant among tetracycline-resistant 
isolates of the animal pathogen Arcanobacterium pyogenes. J. Am. Soc. Microbiol. 46:1281-1287.

Bonnett, B. N., S. W. Martin, V. P. J. Gannon, R. B. Miller, and W. G. Etherington. 1991. Endometrial biopsy in Holstein-Friesian dairy cows. III. Bacteriological analysis and correlations with histological findings. Can. J. Vet. Res. 55:168-173.

Chang, L. L., T. M. Chang, and C. Y. Chang. 2007. Variable gene cassette patterns of class 1 integron-associated drug-resistant Escherichia coli in Taiwan. Kaohsiung J. Med. Sci. 23:273-280.

Clinical and Laboratory Standards Institute. 2007. Performance standards for antimicrobial disk and dilution susceptibility tests for bacteria isolated from animals. Approved standard M31-A3. 3rd ed. Clin. Lab. Stand. Inst., Wayne, PA.

Cohen, R. O., R. Colodner, G. Ziv, and J. Keness. 1996. Isolation and antimicrobial susceptibility of obligate anaerobic bacteria recovered from the uteri of dairy cows with retained fetal membranes and postparturient endometritis. Zentralbl. Veterinarmed. B 43:193199

Collis, C. M., and R. M. Hall. 1992. Gene cassettes from the insert region of integrons are excised as covalently closed circles. Mol. Microbiol. 6:2875-2885.

Ertaș, H. B., A. Kiliç, G. Özbey, and A. Muz. 2005. Isolation of Arcanobacterium (Actinomyces) pyogenes from abscessed cattle kidney and identification by PCR. Turk. J. Vet. Anim. Sci. 29:455-459.

Földi, J., M. Kulcsár, A. Pécsi, B. Huyghe, C. de Sa, J. A. Lohuis, P. Cox, and G. Huszenicza. 2006. Bacterial complication of postpartum uterine involution in cattle. Anim. Reprod. Sci. 96:265-281.

Gilbert, R. O., S. T. Shin, C. L. Guard, H. N. Erb, and M. Frajblat. 2005. Prevalence of endometritis and its effects on reproductive performance of dairy cows. Theriogenology 64:1879-1888.

Gröhn, Y. T., D. J. Wilson, R. N. González, J. A. Hertl, H. Schulte, G. Bennett, and Y. H. Schukken. 2004. Effect of pathogenspecific clinical mastitis on milk yield in dairy cows. J. Dairy Sci. 87:3358-3374.

Guerin-Faublee, V., J. P. Flandrois, E. Broue, F. Tupin, and Y. Richard. 1993. Actinomyces pyogenes: Susceptibility of 103 clinical isolates to 22 antimicrobial agents. Vet. Res. 24:251-259.

Hall, R. M., and C. M. Collis. 1995. Mobile gene cassettes and integons: Capture and spread of genes by site-specific recombination. Mol. Microbiol. 15:593-600.

Jost, B. H., A. C. Field, H. T. Trinh, J. G. Songer, and S. J. Billington. 2003. Tylosin resistance in Arcanobacterium pyogenes is encoded by an ErmX determinant. Antimicrob. Agents Chemother. 47:3519-3524.

Jost, B. H., K. W. Post, J. G. Songer, and S. J. Billington. 2002. Isolation of Arcanobacterium pyogenes from the porcine gastric mucosa. Vet. Res. Commun. 26:419-425.

Jost, B. H., H. T. Trinh, J. G. Songer, and S. J. Billington. 2004. A second thlosin resistance determinant, $\operatorname{ErmB}$, in Arcanobacterium pyogenes. Antimicrob. Agents Chemother. 48:721-727.

Kang, S. G., D. Y. Lee, S. J. Shin, J. M. Ahn, and H. S. Yoo. 2005 Changes in patterns of antimicrobial susceptibility and class 1 integron carriage among Escherichia coli isolates. J. Vet. Sci. $6: 201-205$.

Keyes, K., C. Hudson, J. J. Maurer, S. Thayer, D. G. White, and M. D. Lee. 2000. Detection of florfenicol resistance genes in Escherichia coli isolated from sick chickens. Antimicrob. Agents Chemother. 44:421-424.
LeBlanc, S. J. 2008. Postpartum uterine disease and dairy herd reproductive performance: A review. Vet. J. 176:102-114.

Lehtolainen, T., A. Shwimmer, N. Y. Shpigel, T. Honkanen-Buzalski, and S. Pyörälä. 2003. In vitro antimicrobial susceptibility of Escherichia coli isolates from clinical bovine mastitis in Finland and Israel. J. Dairy Sci. 86:3927-3932.

Narayanan, S., T. G. Nagaraja, N. Wallace, J. Staats, M. M. Chengappa, and R. D. Oberst. 1998. Biochemical and ribotypic comparison of Actinomyces pyogenes and Actinomyces pyogenes-like organisms from liver abscesses, ruminal wall and ruminal content of cattle. Am. J. Vet. Res. 59:271-276.

Nolte, O., J. Morscher, H. E. Weiss, and H. Sonntag. 2001 Autovaccination of dairy cows to treat post partum metritis caused by Actinomyces pyogenes. Vaccine 19:3146-3153.

Pitkälä, A., M. Haveri, S. Pyörälä, V. Myllys, and T. HonkanenBuzalski. 2004. Bovine mastitis in Finland 2001-Prevalence, distribution of bacteria, and antimicrobial resistance. J. Dairy Sci. 87:2433-2441.

Ramos, C. P., G. Foster, and M. D. Collin. 1997. Phylogenetic analysis of the genus Actinomyces based on $16 \mathrm{~S}$ rRNA gene sequences: Description of Arcanobacterium phocae sp. nov., Arcanobacterium bernardiae comb. nov., and Arcanobacterium pyogenes comb. nov. Int. J. Syst. Bacteriol. 47:46-53.

Rodríguez, I., M. R. Rodicio, S. Herrera-León, A. Echeita, and M. C. Mendoza. 2008. Class 1 integrons in multidrug-resistant nontyphoidal Salmonella enterica isolated in Spain between 2002 and 2004. Int. J. Antimicrob. Agents 32:158-164.

Rowe-Magnus, D. A., A. M. Guerout, and D. Mazel. 2002. Bacterial resistance evolution by recruitment of super integron gene cassettes. Mol. Microbiol. 43:1657-1669.

Rutter, B., A. F. Russo, and E. F. Capdevielle. 1999. Isolation of bacteria from dairy cows after normal parturition and assisted parturition with puerperal disorders. Vet. Argent. 16:731-739.

Sheldon, I. M., M. Bushnell, J. Montgomery, and A. N. Rycroft. 2004 Minimum inhibitory concentrations of some antimicrobial drugs against bacteria causing uterine infections in cattle. Vet. Rec. 155:383-387.

Sheldon, I. M., G. S. Lewis, S. LeBlanc, and R. O. Gilbert. 2006 Defining postpartum uterine disease in cattle. Theriogenology 65:1516-1530.

Sheldon, I. M., E. J. Williams, A. N. Miller, D. M. Nash, and S Herath. 2008. Uterine disease in cattle afeter parturition. Vet. J. 176:115-121.

Steffan, J., M. Agric, S. Adriamanga, and M. Thibier. 1984. Treatment of metritis with antibiotics or prostaglandin $\mathrm{F}_{2}$ alpha and influence of ovarian cyclicity in dairy cows. Am. J. Vet. Res. 45:10901094.

Trinh, H. T., S. J. Billington, A. C. Field, J. G. Songer, and B. H. Jost. 2002. Susceptibility of Arcanobacterium pyogenes from different sources to tetracycline, macrolide and lincosamide antimicrobial agents. Vet. Microbiol. 85:353-359.

Wang, G. Q., C. M. Wu, X. D. Du, Z. Q. Shen, L. H. Song, X. Chen, and J. Z. Shen. 2008. Characterization of integrons-mediated antimicrobial resistance among Escherichia coli strains isolated from bovine mastitis. Vet. Microbiol. 127:73-78.

Weisburg, W. G., S. M. Barns, D. A. Pelletier, and D. J. Lane. 1991. $16 \mathrm{~S}$ ribosomal DNA amplification for phylogenetic study. J Bacteriol. 173:697-703. 